Review

\title{
Green(er) Cities and Their Citizens: Insights from the Participatory Budget of Lisbon ${ }^{+}$
}

\author{
Roberto Falanga $^{1, *(\mathbb{D})}$, Jessica Verheij ${ }^{2} \mathbb{D}$ and Olivia Bina ${ }^{1,3}$ \\ 1 Instituto de Ciências Sociais, Universidade de Lisboa, Avenida Professor Aníbal de Bettencourt 9, \\ 1600-189 Lisbon, Portugal; o.c.bina.92@cantab.net \\ 2 Institute of Geography \& Center for Regional Economic Development (CRED), University of Bern, \\ 3012 Bern, Switzerland; jessica.verheij@giub.unibe.ch \\ 3 Geography \& Resource Management, The Chinese University of Hong Kong, Hong Kong, China \\ * Correspondence: roberto.falanga@ics.ulisboa.pt \\ + This article was presented at the International Symposium on Nature-Based Solutions "Greening Cities \\ Shaping Cities", Milan, Italy, 12-13 October 2020.
}

Citation: Falanga, R.; Verheij, J.; Bina, O. Green(er) Cities and Their Citizens: Insights from the Participatory

Budget of Lisbon. Sustainability 2021, 13, 8243. https://doi.org/10.3390/ su13158243

\section{Academic Editors: Israa}

H. Mahmoud, Eugenio Morello, Giuseppe Salvia and Emma Puerari

Received: 7 April 2021

Accepted: 19 July 2021

Published: 23 July 2021

Publisher's Note: MDPI stays neutral with regard to jurisdictional claims in published maps and institutional affiliations.

Copyright: (C) 2021 by the authors. Licensee MDPI, Basel, Switzerland. This article is an open access article distributed under the terms and conditions of the Creative Commons Attribution (CC BY) license (https:// creativecommons.org/licenses/by/ $4.0 /)$.

\begin{abstract}
There is rising scholarly and political interest in participatory budgets and their potential to advance urban sustainability. This article aims to contribute to this field of study through the specific lens of the city of Lisbon's experience as an internationally acknowledged leader in participatory budgeting. To this end, the article critically examines the lessons and potential contribution of the Lisbon Participatory Budget through a multimethod approach. Emerging trends and variations of citizen proposals, projects, votes, and public funding are analysed in tandem with emerging key topics that show links and trade-offs between locally embedded participation and the international discourse on urban sustainability. Our analysis reveals three interconnected findings: first, the achievements of the Lisbon Participatory Budget show the potential to counteract the dominant engineered approach to urban sustainability; second, trends and variations of the achievements depend on both citizens' voice and the significant influence of the city council through policymaking; and, third, the shift towards a thematic Green Participatory Budget in 2020 was not driven by consolidated social and political awareness on the achievements, suggesting that more could be achieved through the 2021 urban sustainability oriented Participatory Budget. We conclude recommending that this kind of analysis should be systematically carried out and disseminated within city council departments, promoting much needed internal awareness of PBs' potential as drivers of urban sustainability. We also identify further research needed into the sustainability potential of green PBs.
\end{abstract}

Keywords: participatory budget; urban sustainability; European green capital; European green deal; Lisbon

\section{Introduction}

In the last few decades, spreading scepticism towards democratically elected governments and their institutions, along with a shared need to improve democratic decisionmaking, has convinced public authorities to promote participatory processes in policy making [1,2]. At the end of the 1980s, a particular category of participatory practices came to the fore: Participatory Budgets (PB hereafter). Initiated in Latin America, PBs provided new impetus to participatory processes by allocating a share of the local public budget to citizen-led initiatives. While aiming to get the most marginalised groups of civil society closer to democratic institutions and representatives, PBs were celebrated by movements and parties on the left of the political spectrum for their capacity to foster social justice, transparency, and accountability [3,4]. During the 1990s and 2000s, international agencies such as the World Bank, United Nations, Organisation for Economic Cooperation and Development, and European Union endorsed the PB for its potential to recover citizenry trust towards democracy. The magnitude of its dissemination reached the five continents, with 
higher rates in Latin America and Europe [5]. The disruption of the Covid-19 pandemic, however, has had major impacts over the implementation of participatory processes in general and PBs in particular, as public authorities were required to prioritise immediate responses to the global contagion of the coronavirus, at the expense of PB projects [6].

In 2019, Portugal was the European country with the highest rate of local PBs implemented out of a national legal framework [5]. The enthusiasm around the PB dates to the early 2000s and then grew exponentially after the Lisbon PB in 2008/2009 [7], which marked the first city-wide PB implemented by a European capital and introduced a new model of direct participation. Citizens have since been invited to submit and vote ideas for public funding in all policy domains, including urban sustainability within the thematic area "environment, green structure, and energy". However, only in 2020 did a more explicit and tangible link emerge between Lisbon's PB and urban sustainability. As Lisbon received the European Green Capital Award (EGCA hereafter) and subsequently announced the launch of a Green $\mathrm{PB}$, it raised great interest worldwide. This promising turn of events and of policy attention towards more sustainable urban agendas was shaken by the global pandemic (Covid-19), yet, as we will see, the city council strove to keep its political promise to shift the thematic focus of the PB towards urban sustainability, incorporating the European Green Deal into the 2021 version of the Lisbon PB.

The recent global pandemic has added to the already abundant calls for greater attention to the health of ecosystems and to the negative impacts of rapid urbanisation and of cities on local and global sustainability [8,9]. Two notable trends seem relevant here: first, the growing role of cities in national and international agreements promoting sustainability (see Sustainable Development Goal 11, UN General Assembly 2015) and related agendas for climate mitigation and adaptation, and reducing biodiversity loss [10]; second, the growing demand for nature-based solutions which identifies the participation of citizens and businesses as key [11,12]. Hence, this article aims to contribute to the participatory dimension of urban sustainability agendas through the specific lens of participatory budgets, by asking what the lessons and potential contribution of the Lisbon PB experience are in advancing urban sustainability. To this end, we first describe the key concepts for our inquiry into participatory budgeting and urban sustainability, by then focusing on the case study of Lisbon's accumulated experience of $11 \mathrm{~PB}$ editions and its ongoing thematic shift towards a Green PB in 2020, followed by a "sustainability-oriented" PB in 2021. After presenting our mixed-method approach based on the analysis of grey literature, of statistical data on the 11 PB editions, and of four semi-structured interviews with key local actors, we discuss our findings by highlighting emerging trends and variations throughout Lisbon's PB experience. This analysis allows us to identify the most common urban sustainability topics proposed by citizens. We will show that the Lisbon PB has had remarkable success in attracting citizen proposals and funding projects in key areas of urban sustainability, covering topics that often go beyond the more technocratic focus on green spaces and infrastructure present in international agendas of climate change and biodiversity loss. We go on to argue that $\mathrm{PB}$ achievements are to be understood within the context and framework of the public agendas set by city councils, as these influence trends and variations within the PB program. We also found that the pursuit of pedagogical and instrumental purposes in shifting towards a thematic PB is based on a rather weak evidence-based awareness about the PB's contribution in this field. We conclude by recommending that this kind of analysis should be systematically carried out and disseminated within city council departments, promoting much needed internal awareness of PBs' potential as driver of urban sustainability. We also identify further research needs regarding the sustainability potential of green PBs.

\section{Conceptual Framework: Urban Sustainability and Citizen Participation}

Since the origins of the concept of sustainable development based on the balance between ecological sustainability and human needs, the urban dimension has been a significant part of the global debate. Already the Brundtland Report of 1987 referred to "the 
urban challenge" by addressing extreme forms of urbanisation as associated with growing social and environmental problems [13]. However, whereas initially cities tended to be considered mainly as hotspots of environmental hazards, and still are [14], the idea of urban sustainable development nonetheless gained momentum, as urban governments became increasingly seen as drivers of positive change. In the last few years, local governments have sought to implement policies to reduce their ecological footprint and gained international projection [15] for being considered an appropriate administrative level to enable changes in everyday structures and behaviours in the face of global climate change. Hence, sustainability processes are nowadays often analysed on city level, linking environmental improvements to local economic development $[16,17]$.

This trend culminated in 2015 with the inclusion of a specific "urban" goal in the 17 Sustainable Development Goals [18], which re-energised the momentum initiated with the Rio Conference in 1992 [19], and the more recent UN New Urban Agenda in 2017 [20]. SDG 11 addresses the challenges faced within urban contexts, while going "far beyond the typical focus on housing and slum upgrading" ([21], p. 94) to also include targets related to climate resiliency, waste management, public space, mobility systems, and, ultimately, forms of participatory planning. Nonetheless, the concept of urban sustainability is often criticized for being an oxymoron [22], not addressing the inevitable trade-offs between the environmental, economic, and social dimensions of sustainability $[23,24]$. The essence of this critique lays in the fact that urban sustainability itself falls short to define what is to be sustained, by whom, and for whom [25].

While the understanding of urban sustainability can range from approaches focusing mostly on the environmental dimension towards others prioritising social justice and well-being [24], the human dimension has gained a more prevalent role during the 1990s. "Social sustainability" has since been evoked to highlight the interdependence between social, economic, and environmental goals $[25,26]$ with a growing concern towards policies aiming to eradicate poverty and social exclusion [26]. In this regard, the need to mitigate environmental hazards is increasingly being linked to calls for wider citizen participation, in order to provide local communities with new conditions to improve their quality of life [27]. Experiments of co-design and co-production of knowledge [28] through transdisciplinary practices [29] have further allowed delving into the contested character of urban sustainability. In addition, international agencies have equally emphasised the role of public participation in creating a shared vision of cities' future by ensuring the inclusion of different social groups [30].

Scholars contend that the development of participatory processes with citizens provides evidence for effectively supporting environmental policies and reducing the risk of future backlashes [31]. As residents have a chance to shape the development of their neighbourhood or city, solutions are likely to be more aligned to local needs and aspirations [32], as shown in seminal experiences under the "Global Agenda 21" [19]. In some cases, participatory initiatives create new opportunities for partnerships in the management of specific projects [33-35] either led by public agencies or grassroots groups [36,37], and possibly develop into more extensive sustainability programmes [38]. When participation is prompted for the strategic planning of green infrastructures and services $[35,39,40]$, new links can be created among ecological, economic, and societal elements of urban sustainability [41].

Acknowledging the potential of citizen participation for urban sustainability, Hayward [42] suggests looking at participatory processes through the lenses either a deliberative or participatory approach. The former aims at giving the opportunity to a selected poll of citizens to reflect on socio-ecological and human systems [43]. In this type of settings, citizens are asked to construct a new ecological rationality [44], possibly reliant upon multiple governance arrangements [45]. In some cases, deliberative initiatives also engage experts to foster the public debate with citizens, although this may raise concerns as to the growing distrust towards science and political power in green thinking $[46,47]$. Participatory approaches are rather concentrated on the sharing of power among multiple agents and are more frequently open to the participation of all citizens [48]. Along with 
participatory experiences in the field of urban planning [49], the PB is the most known participatory process that encompasses mechanisms aimed at collecting proposals from citizens and allocate public funding for their implementation [50]. However, while the uptake of PBs worldwide has been significant, little is known about its actual contribution to advance urban sustainability.

In a recent publication, Cabannes [51] notes that there are few internationally documented PBs that have put environmental issues at the centre of the public debate. Yet those that have done so have shown a promising potential to bridge public debates with concrete actions on climate change. Scholars hold, in fact, that funding community projects through the PB provides citizens with greater know-how in taking the lead of environmental projects [52], as well as higher degrees of control over service delivery and goals of redistributive justice [53]. Other scholars, however, cast light on potential risks, as PBs may incorporate the urban sustainability agenda because of budget cuts imposed on local authorities, particularly in the aftermath of the financial crisis [34], resonating with those who claim that the welfare state has been significantly narrowed, especially in the peripheral Eurozone [54]. The question on whether PBs can contribute to advance urban sustainability, thus, remains open, as evidence is needed to substantiate hopes and promises about its potential.

\section{The Lisbon Participatory Budget}

Portugal was one of the most affected countries of the 2008 financial crisis in Europe, eventually entering an international bailout provided by the International Monetary Fund together with the European Bank and the European Commission from 2011 to 2014. Like in other peripheral Eurozone member states, budgetary cuts imposed on local authorities were significant [55], which led policymakers to search for innovative and effective mechanisms of participatory governance. Likewise, the first Lisbon PB in 2008/2009 gave citizens the possibility to submit and vote project ideas across all policy domains. Over the last decade, the Lisbon PB was run based on a yearly cycle with a dedicated budget of 5 million euros in the first editions, later cut to 2.5 million in 2012, which, according to the city council, was a direct consequence of the austerity measures. The Lisbon PB was the first PB implemented on a municipal scale by a European capital, having a major impact over the dissemination of PBs in Portugal and reverberation at the international level $[7,56]$.

Available data show that from 2008 to 2018 the PB has received a total number of 2073 proposals from citizens: 139 out of them were funded based on citizen voting, which covered slightly more than a 36-million-euro budget. Today, the Lisbon PB is one of the longest-running PBs in the country and has recently been awarded as the best 2020 participatory practice by the national network of participatory city councils in Portugal (More information at: https://op.lisboaparticipa.pt/, accessed on 12 June 2021). Some scholars have pointed out how the Lisbon PB has contributed to advance urban sustainability, as distinguished by van der Jagt and colleagues [34] in their extensive analysis of 20 cities in 14 EU-countries. Buijs and colleagues [57] similarly suggest that the Lisbon PB provided new conditions for citizens to influence the decision-making and improve their understanding of the implications of urban sustainability, based on the many sustainability-oriented projects funded through the PB, such as paths, parks, gardens, and ecological corridors. "The success in Lisbon is that citizen concern for their urban environment was captured by the L-PB [Lisbon PB] process. It may also be the case that the L-PB process increased awareness of the relevance of green to the public" [57] (p. 42).

In 2019, a collaboration between the Lisbon city council and the European agency Climate KIC led to a trial of a PB for schools, dedicated to encouraging the participation of youngsters in sustainability projects [51]. At the same time, the creation of a PB Green Seal aimed at recognising PB proposals with a focus on urban sustainability. These actions can be considered as a proxy to the forthcoming 2020 Green PB, announced by the Mayor in October 2019 in light of the 2020 European Green Capital Award (EGCA) - the first time a capital city from a Southern-European country received this award (The European 
Green Capital Award is an initiative launched in 2008 by the European Commission to celebrate and recognize cities' achievements in terms of urban sustainability and to provide role-models for other European cities. Any city government can apply for the award by submitting an application, and every year a jury selects one city for its efforts and consistent record of high environmental standards. The award is meant to serve as a platform for policy-sharing and inspiration, as the European Green Capital shares its best-practices and experience with other cities. More information about the European Green Capital Award: https:/ / ec.europa.eu/environment/europeangreencapital/winning-cities/2020 -lisbon/, accessed on 5 May 2021). The Green PB was one of the various actions planned for 2020, together with tree-planting programs, the (re)opening of a (renewed) public green space each month of the year, and the implementation of a reduced-emissionszone in Lisbon's downtown. The Green PB was understood as the first PB of its kind, despite other cities having invested in similar programs, as in the case of Lublin (Poland), Brussels (Belgium), Odemira (Portugal), and Matz and Bordeaux (France). However, neither embraced urban sustainability as an exclusive thematic focus or made available full information regarding procedures and outputs.

Since the Covid-19 pandemic eventually forced the Lisbon city council to suspend the Green PB in 2020, the 2021 edition went on to recover and enhance the intention to shift towards a thematic PB. This time, the Lisbon PB is oriented to promote urban sustainability as framed within the recently-issued European Green Deal and its several action areas. In addition, the $2021 \mathrm{~PB}$ added one specific thematic area concerning physical and mental health as well as sport, to encourage citizen proposals in response to the impacts of the pandemic and support the as agenda linked to the European Capital of Sport. Given its scope, the PB shows a significant capacity to readapt its design to dramatic contingencies and build on the international debate on sustainability. Despite the ongoing crisis, and going beyond the $\mathrm{PB}$, the city intends to implement significant environmental changes to ensure sustainable land use, green infrastructure, and water management. As enshrined in the 2012 Lisbon master plan and later highlighted by the Lisbon's Action Plan for Biodiversity published in 2015, the city aims to expand its green infrastructure by over 200 hectares and create linkages between different green areas through so-called green corridors. In the last few years, the city has invested in developing a more sustainable mobility system based on public transport and cycle networks and has become involved in climate change adaptation and mitigation, culminating into the publication of its Strategy for Climate Change Adaptation in 2017 with a strong commitment to reducing greenhouse gas emissions.

\section{Methodology}

Our interest was raised by the combination of the international achievements of Lisbon in the fields of participatory budgeting and urban sustainability, which culminated in the announcement of the Green PB in 2020, followed by the 2021 sustainability-oriented PB edition framed within the European Green Deal. Our research asked what the lessons and potential contributions are of the Lisbon PB experience in advancing urban sustainability, and specifically seeks to understand its contribution throughout the past 11 editions. In addition, we ask whether its thematic shift towards sustainability relied upon a shared understanding of its achievements. To this end, we analysed the past 11 PB editions by means of a mixed-method approach, as synthetised in the Table 1 below.

Firstly, we conducted an analysis of the policy documents produced on the integration of urban sustainability agenda into the Lisbon PB. We took into account three primary sources: (i) the PB "Charter of Principles" issued in 2008, which has guided this process thus far; (ii) the yearly evaluation reports of each one of the $11 \mathrm{~PB}$ editions, available on the city council's website; and (iii) the Lisbon application to the EGCA, including its evaluation by the evaluation board. The analysis was conducted between April 2018 and September 2020 to provide a focussed overview of the main arguments posed by the official policy discourse. 
Table 1. Methods and goals.

\begin{tabular}{cc}
\hline Methods & Goals \\
\hline Analysis of grey literature. & $\begin{array}{c}\text { Provide a comprehensive understanding of the } \\
\text { official policy discourse on the Lisbon PB } \\
\text { Provide an evidence-based overview of the } \\
\text { Quantitative and qualitative data analysis } \\
\text { of past PB editions (or statistical analysis) }\end{array}$ \\
Expert interviews & Provide complementary data from situated \\
knowledge of key actors
\end{tabular}

Secondly, we collected and analysed data on all citizen proposals selected for public voting and funded projects in the PB from 2008/2009 to 2018. We focussed on proposals and projects listed in one of the nine thematic areas defined by the $\mathrm{PB}$, namely, "environment, green structure, and energy". This is due to the fact that, according to our conceptual framework, this theme condenses the main tenets of the urban sustainability agenda. Data collection was based on the systematic consultation of the PB website, oriented by a twofold purpose: on a quantitative stance, we aimed to draw a comprehensive picture of trends and variations of proposals submitted by citizens, citizen votes to the proposals, winning projects (i.e., proposals to be implemented as a result of citizens' voting), and public funding allocated for the implementation of projects. On a qualitative stance, we aimed to make sense of the thematic area by analysing the content of citizen proposals by identifying emerging key topics.

Thirdly, we interviewed four key actors to account for their personal perspectives on $\mathrm{PB}$ and the urban sustainability agenda in Lisbon. Interviews were conducted with the advisor in charge of the KIC Climate for the design of the Lisbon Green Seal and the PB for schools; the head of the municipal direction for participation; the PB coordinator; and an internal advisor to the municipal councillor for environment, green structure, climate, and energy who coordinated the Lisbon EGCA application.

\section{Findings}

Findings are presented below by following the same order of the section above. Accordingly, we first examine findings from the document analysis; secondly, we delve into the data retrieved from the consultation of the 11 PB editions; and, lastly, we highlight the main arguments provided by our four interviewees.

\subsection{Document Analysis}

The PB "Charter of Principles" is meant to guide the implementation of the PB according to eight propositions: (i) to promote participatory democracy as issued by the Portuguese Constitution; (ii) to foster the following goals: active citizenship, civic education, policy responsiveness, and transparency; (iii) to share power with citizens by giving them the opportunity to propose and vote new public measures; (iv) to multiply channels of participation, both face-to-face and online to ensure its reach; (v) to organise the PB through sequential steps on a yearly basis; (vi) to make available and accessible information related to the $\mathrm{PB}$; (vii) to be accountable on the implementation of projects; (viii) to monitor and assess the PB in order to adapt the process to emerging needs. This chart provides the political and administrative framework to enhance the city council's capacity to learn from citizens' input and provide them with a voice into decision making through the PB. Considering these eight propositions, the analysis of the yearly PB reports shows the impacts of political decisions over the institutional design of this process, which demonstrates a great adaptative nature to the local sociopolitical setting.

The PB reports permit providing insights on the most remarkable changes, such as the reduction of the budget from 5 million to 2.5 million euros in 2012 (and still in place). While no public information is made available on the budgetary weight of the PB since 2008 , it is possible to collect data from the $2019 \mathrm{~PB}$, which represents around $0.4 \%$ of public investment in the city budget. Considering the remarkable cut operated in 2012 
and the inflating economy of Lisbon in the last few years, these data are likely to have sensibly changed over time. Allegretti and Antunes [56] argue, in fact, that up to the 2012 cut, the Lisbon PB corresponded to $5.4 \%$ of the investment capacity of the municipality. Nevertheless, this change did not affect the participation of citizens in significant ways, as shown in the analysis described below. Moreover, in 2021, new criteria for the spatial distribution of citizen proposals were introduced. Proposals have since been divided into city-wide (up to 500.000 euros each) and neighbourhood-based proposals (up to 150.000 euros each), which is expected to better respond to citizens' needs according to the implementation scale of the projects. The analysis of the PB reports further informs on changes adopted in the channels of participation, as the first two PB editions were run online only, followed by a mixed face-to-face and online version from 2010 onwards. Provided with multiple channels, the PB was expected to improve its reach in the city and include citizens via local meetings, and online through the PB official website. These changes were in place until the 2018 PB edition.

The growing importance of the PB as a key space for citizen engagement motivated the city council to emphasize its potential in its application to the ECGA, stressing its role in five out of the twelve indicators of the application form: sustainable mobility, sustainable land use, noise, green growth and eco-innovation and governance(The complete list of topics is: climate change mitigation, climate change adaptation, sustainable urban mobility, sustainable land use, nature and biodiversity, air quality, noise, waste, water, green growth and eco-innovation, energy performance, and governance. The Lisbon application to EGCA was scored high in the indicators of sustainable mobility, sustainable land use and green growth, while it did not score particularly well on the indicators for governance (4 out of 12 ) and noise (6 out of 12). The PB was mostly presented as a flagship of public decision making, however, without providing further details on the sustainability-oriented projects funded through the $\mathrm{PB}$ - despite its clear contribution to the development of green spaces and cycle infrastructure. The evaluation board recognised the PB as a "very well established [practice], with over $€ 31$ million allocated over the past 10 years" [58] (p. 45). The board further appreciated the reference to citizen participation in eco-innovation, as the city owns a set of "[c]lear and concise policy driven plans involving citizens, universities, businesses and foreign partners" [58] (p. 43). Yet, the board contended that it is not always clear which citizens are involved and how, nor what plans are being prepared for the future.

\subsection{Data Analysis}

To better understand the potential disclosed by the PB in this field, we collected data on the thematic area "environment, green structure, and energy" from 2008 to 2018, and focussed on four items: citizens' proposals; votes; projects; and public funding. The figure below puts together findings from the analysis made per PB edition (for more detailed information, see Table A1 in Appendix A). An overview of the emerging trends shows that $38 \%$ of citizen proposals were submitted in the selected thematic area, while around $27 \%$ of the projects were eventually funded in this thematic area. Data about the volume of votes show that around $18 \%$ were made by citizens for projects in this thematic area $(n=54863)$, which corresponded to slightly more than 16 million euros allocated for their implementation (around 44\% of the overall budget, slightly less than 36 million euros).

Figure 1 elucidates the relatively large amount of budget allocated to this field, with a considerable peak at the very beginning of the PB in the city, as the first PB holds a primacy in all rates. The visible drop down in 2012 may be explained by the remarkable changes made in that year, as a response to the financial crisis. Nevertheless, the drop contrasts with a relatively high rate of proposals (36\%) pointing to the significant citizens' interest in the implementation of projects within the thematic area despite the budgetary cut operated in that year. The increase of projects and funding allocated to their implementation in 2016 opposes to the decrease in the number of proposals, which has persisted in 2017 and 2018. To provide a more substantive explanation of these trends and variations, we analysed the 785 citizen proposals selected from 2008 to 2018 in the thematic area. Our goal was to 
better understand the emerging topics related to urban sustainability by disaggregating the official classification of the thematic area. Accordingly, we identified eight key topics:

- Topic 1 'city/neighbourhood': promotion of green initiatives at the neighbourhood and/or city level;

- Topic 2 'recovery': regeneration and green recovery of streets, squares, and public spaces;

- Topic 3 'gardens': improvement and/or creation of new parks and gardens for all and/or for children;

- Topic 4 'farming': creation of new urban farming and gardening;

- Topic 5 'mobility': promotion of sustainable mobility;

- Topic 6 'animals': animal protection;

- $\quad$ Topic 7 'energy': sustainable energy (e.g., street led lighting);

- Topic 8 'pollution': combat air and noise pollution.

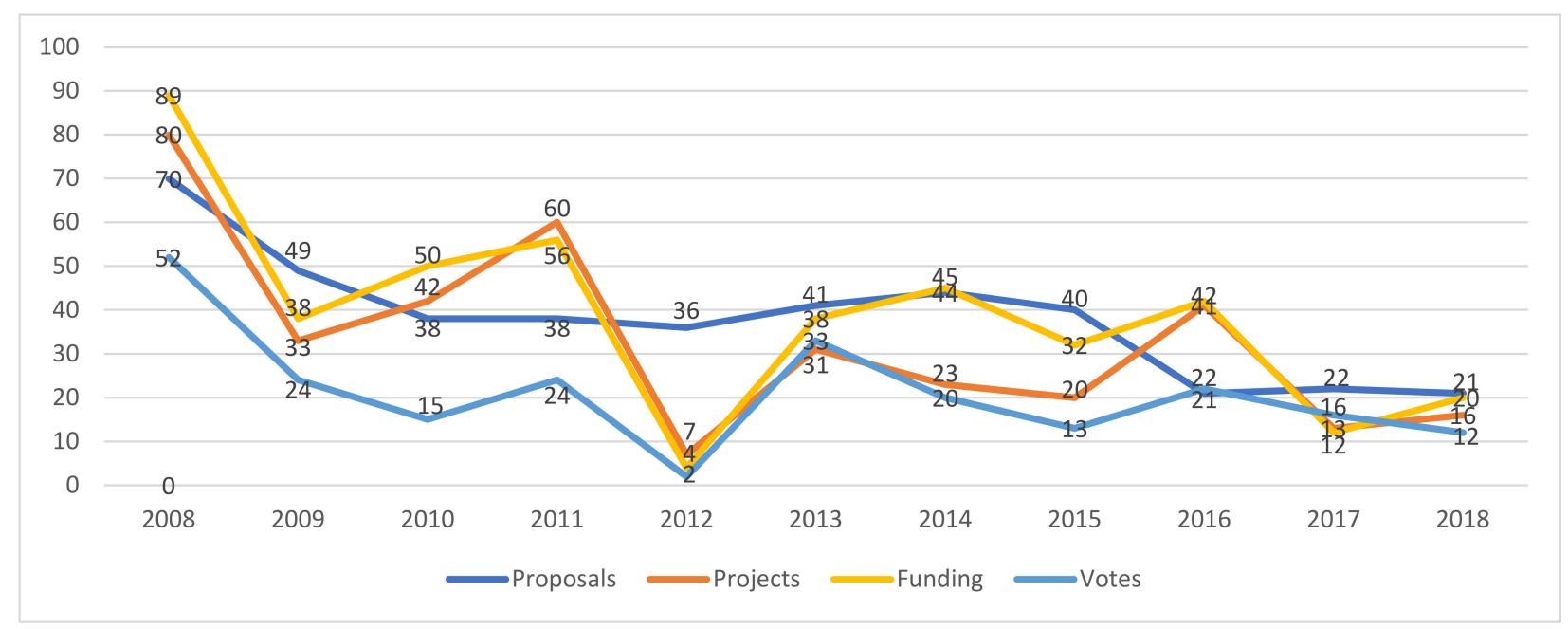

Figure 1. Percentages of proposals, votes, projects, and funding in the "environment, green structure, and energy" thematic area of the Lisbon PB from 2008 to 2018. Data source: Lisbon city council (http:/ /op.lisboaparticipa.pt, accessed on 12 June 2021).

The eight key topics help characterise both qualitatively and quantitatively the most frequent aspects considered by citizens. Figure 2 below shows the rates of citizen proposals per key topic, while extended information about proposals and projects can be found in Table A2 in Appendix B.

The content analysis of citizens' proposals suggests that some topics hold greater consistency, despite the rise and decline of others, as in the case of the first five topics and topic 7 'energy'. Topics 1 'city/neighbourhood', 2 'recovery', and 3 'gardens' are significant throughout the PB editions, the latter peaking in 2016. In contrast, topics 7 'energy' and 8 'pollution' show the lowest rates overall. The inversely proportional relation between topic 3 'gardens' and topic 2 'recovery' is substantiated by the former taking over from the decrease of the latter. Moreover, topics 6 'animals' and 8 'pollution' increased considerably in the last PB editions, whereas topics 5 'mobility' (absent in 2017 and 2018 editions), 4 'farming' and 7 'energy' (absent in the 2018 edition) decreased significantly. To better understand the magnitude of each key topic, we also collected data about the votes made by citizens and the allocated public funding for the implementation of projects from 2008 to 2018 (Table 2). 




Figure 2. Percentages of citizen proposals per key topic in the "environment, green structure, and energy" thematic area of the Lisbon PB from 2008 to 2018. Data source: Lisbon city council (http:/ / op.lisboaparticipa.pt, accessed on 12 June 2021).

Table 2. Votes and public funding allocated per key topic in the "environment, green structure, and energy" thematic area of the Lisbon PB from 2008 to 2018.

\begin{tabular}{ccccc}
\hline Key Topic & $\begin{array}{c}\text { Proposals } \\
\text { (2008-2018) }\end{array}$ & $\begin{array}{c}\text { Projects } \\
\text { (2008-2018) }\end{array}$ & $\begin{array}{c}\text { Votes } \\
\text { (2008-2018) }\end{array}$ & $\begin{array}{c}\text { Funding } \\
\text { (2008-2018) }\end{array}$ \\
\hline 1 & 163 & 3 & 5298 & $1,800,000$ euros \\
'city/neighbourhood' & 223 & 9 & 6494 & $3,250,000$ euros \\
2 'recovery' & 255 & 16 & 31,351 & $6,340,000$ euros \\
3 'gardens' & 31 & 1 & 346 & 150,000 euros \\
4 'farming' & 48 & 2 & 4832 & $3,100,000$ euros \\
5 'mobility' & 30 & 5 & 6382 & 825,000 euros \\
6 'animals' & 16 & 1 & 89 & 500,000 euros \\
7 'energy' & 19 & 1 & 71 & 50,000 euros \\
8 'pollution' & 19 &
\end{tabular}

Highlights from the table above show that topic 3 'gardens' holds the record with more than 30,000 votes received throughout the PB editions and the largest amount of funding, which is consistent with the number of projects implemented throughout the 11 PB editions $(n=16)$. The high rate of votes builds on-at least—a couple of landmark projects that mobilised great support from citizens: the restoration of the Botanic Garden in 2013, and the "Caracol" garden in 2016, the latter gathering 9447 votes, the highest ever in the Lisbon PB. Funding is relatively high in topics 2 'recovery' and 5 'mobility', as well. The latter confirms that, despite the few approved projects $(n=2)$, these can have a significant impact on public spending for demanding a wider approach to urban intervention in the green infrastructure.

\subsection{Interviews}

Exploratory interviews helped us to draw a clearer picture of emerging trends, variations, and topics throughout the $11 \mathrm{~PB}$ editions. Accordingly, we interviewed four key actors: the advisor in charge of the KIC Climate for the design of the Lisbon Green Seal and the PB for schools; the head of the municipal direction for participation; the PB coordinator; and the politically appointed advisor to the municipal councillor for environment, green 
structure, climate, and energy. Interviews took around one hour each and were based on a similar semi-structured approach.

The KIC Climate advisor was interviewed in July 2020 to discuss the progressive tendency of the PB towards urban sustainability themes, with a focus on the Green Seal launched in 2019, which, according to our interviewee, was designed to raise citizens' awareness. The Seal was also conceived as a proxy to the 2020 Green PB through a step-by-step strategy aimed to learn from the past editions and prepare the future of this participatory process. Likewise, the piloting of the PB for schools-focused on themes of sustainability - was thought of as an opportunity for young students to take decisions over a more sustainable future. In September 2020, we interviewed the municipal director of citizen participation and the PB coordinator at the city council. The former emphasised the growing political commitment towards urban sustainability, which found in the PB a potential ally. As the deputy mayor in charge of the PB encouraged a more inclusive and face-to-face approach to participation, the reduction in number of citizens' proposals selected for public voting aimed to ease the internal coordination for the implementation of the projects. In 2018, new "pedagogical goals" mobilised the department of participation that soon embraced the political intention to promote a Green PB in 2020 to encourage behavioural changes in the city. This effort, she contended, did not entail only the incorporation of urban sustainability themes, but rather the capacity to make its values accessible to all through a common language shared between the city council and citizens. In this way, the PB could be approached not as a mere financial tool for the implementation of projects, but rather as a generator of new bridges between the city council and citizens.

Along with pedagogical goals, the PB coordinator reinforced the instrumental purpose of the envisioned transition towards the 2020 Green PB. The thematic focus on urban sustainability implied, according to our interviewee, the opportunity to keep high the international interest on the PB by building upon the connection with the European agency KIC Climate. Most importantly, this shift implied the opportunity to solve the pitfalls of this process regarding the time-demanding analysis of citizens' proposals in all policy areas and implementation of projects. Both stages are coordinated by the PB team with other municipal departments, which ends up increasing the red tape and slowing project implementation (see also [59]), with implications over the credibility of the PB with citizens.

Lastly, the interview with the internal advisor to the councillor responsible for Lisbon's application to the European Green Capital Award allowed us to better position the PB within the urban sustainability agenda pursued by the city council. While the interview focused mainly on the development of Lisbon's Green Infrastructure from an urban planning perspective, it gave important insights into the city's journey towards being acknowledged with the title of 2020 European Green Capital. The winning application submitted in 2017 was the third application submitted by Lisbon, having reached second place the previous year. According to our interviewee, the EGCA communicated in 2018 had an additional impact over the EGC programme: based on the city's track record with participatory processes, the EGC assessment formula for indicator 12 ("Governance") was changed slightly to include an explicit reference to "Partnerships and Public Involvement". As a result, from 2019 onwards, applicant cities are required to describe their strategies for citizen participation, which should be considered, according to our interviewee, an important contribution of Lisbon's application.

\section{Discussion}

The inclusion of a thematic focus on urban sustainability, which was planned for the 2020 PB edition and then took place in 2021 by incorporating the European Green Deal action areas, is a turning point in the history of the Lisbon PB. Scholars contend that citizen participation can effectively contribute to advance urban sustainability [42,51], and the Lisbon PB seems to prove efficacy in allocating public funding to local issues perceived as most pressing or urgent in this field [26]. This process further shows that, despite the considerable cuts induced on the available budget in 2012, public engagement has been 
relatively high throughout the 11 editions, with a more visible decrease in numbers over the last few editions. Bearing this in mind, and relying upon evidence retrieved from our study, our discussion develops around three main findings.

Firstly, data show that the Lisbon PB aligns with urban sustainability goals and seems to counteract the dominant engineered approach towards sustainability, focused on green growth and innovation. As Gulsrud and colleagues [60] stress, the international agenda tends to undermine 'ecological green resources' (e.g., parks, trees, grassland, water bodies, etc.) by prioritising short-term deliverables (e.g., cycle paths, storm-water channels, footpaths and access routes, energy-efficient built environment) in detriment of biophysical achievements. In Lisbon, the authors (ibidem) contend that some of these trends reverberate in the unbalanced commitment to planning public spaces and nature-based solutions beyond the city boundaries, while additional criticisms are raised as to the capacity of the city to address rising real estate prices and social exclusion (cf. [61]). Against this background, our findings show that the PB contrasts with the otherwise dominant focus on green growth and eco-innovation of several other policy programmes, including the ECGA [62]. Despite the slow decline over the last years, findings show that around 33\% of citizen proposals and projects, $18 \%$ of votes, and $44 \%$ of public funding are dedicated to the "environment, green structure, and energy" thematic area of the PB. Interestingly, these outcomes align only partially to the emphasis put by international agendas on urban infrastructure. Instead, other topics, often excluded from the dominant agenda on sustainability, are prevalent in the $\mathrm{PB}$, as is the case of animal protection. We therefore note the potential of a green PB to promote a more balanced approach to socio-ecological challenges, while counteracting an engineering-led discourse of urban sustainability present in, among others, the EGCA. Scholars have argued that this approach reduces the opportunity to promote equitable, inclusive urban transitions [62]. Hence, given Portugal's challenging economic context of the last decade and the correlation between national wealth and the performance of Europe's capital cities in terms of sustainability [16], this contribution of the Lisbon PB towards urban sustainability is particularly valuable.

At the time of writing, the 2021 Lisbon PB is being implemented with a 2.5-millioneuro budget. Preliminary data show a sensible decrease of citizen participation at the stage of proposals' submission $(=251)$, and only 75 out of them considered for public voting. An overview on the distribution of proposals in the new eight thematic areas shows a preponderance of the mental and physical health and sport theme $(n=75)$, followed by smart and sustainable mobility $(n=45)$, adaptation and mitigation of climate changes $(n=43)$, and reduction of pollution and promotion of biodiversity $(n=41)$. Circular economy and efficient building collected the same number of proposals $(n=16)$, followed by the promotion of just food systems $(n=10)$, and only 5 proposals for clean and renewable energy. The decrease in numbers of proposals should be analysed attentively in the future, taking into consideration the impacts of the pandemic in the field of citizen participation [6]. At the moment, we can only speculate about possible reasons behind this decline, as these data can either reveal a process of cultural accommodation to the thematic shift, or the adoption of online tools only due to the restrictions of the Covid-19 pandemic. These data may also indicate a mounting disillusionment regarding the PB as a policy mechanism, out of any direct correlation with urban sustainability themes.

Secondly, PB achievements should be understood in light of the local agenda and public action of the city council. The $2012 \mathrm{~PB}$ edition represented a turning point due to cuts in the allocated budget from 5 to 2.5 million euros and the distribution of the budget into city-wide projects and smaller interventions at the neighbourhood level, which all seemed to influence the decrease in votes, projects, and allocated budget, but not proposals. As citizen interest around urban sustainability remained high up to 2016, the last few PB editions showed a decrease in proposals, contrasting with a relatively high number of votes, projects, and allocated funding. This variation can be traced back to changes prompted under the deputy mayor in charge of the $\mathrm{PB}$, who aimed to reduce the number of citizen proposals selected for public voting to ease the red tape and, later in 2018, to 
boost a new pedagogical ethos to prepare the shift towards the 2020 Green PB. Also in 2016, the 'Caracol' garden, one of the most emblematic PB projects for urban sustainability, was funded with a record number of votes. This project relied upon an unprecedented citizen mobilisation that reverberated citizen support for the restauration of the Botanic garden in 2013, which attracted one of the highest rates of votes ever. As pointed out by Allegretti and Antunes [55], the social dynamics behind the submission of citizen proposals heavily rely upon pre-existing networks and interest groups, which often explain the success of specific projects in the Lisbon PB.

The impact of the two garden projects can be understood in the framework of the identified key topics, where topic 3 'gardens' emerges as the most frequent. Its progressive growth throughout the $11 \mathrm{~PB}$ editions emphasises the decrease of topic 2 'recovery'. This inverse relation may relate to a broader shift in the public discourse and citizen understanding of urban sustainability in Lisbon, as the focus on the quality of green public spaces seems to prevail over the more infrastructure-based interventions aimed at improving streets and squares, as argued above. This hypothesis is also substantiated by empirical knowledge about the city council's action in this field, which plays a key role in managing significant trade-offs of urban development [23], with implications on governance tools, as in the case of the PB. For example, the lack of proposals in Topics 4 'farming' and 7 'energy' in the last edition, as well as the absence of proposals in Topic 5 'mobility' in the last couple of editions, can be traced back to the mainstreaming of urban policies in these fields, which reduced public demand when it comes to PB processes.

Thirdly, our interviews suggest that the shift towards a thematic PB in 2020 was primarily seen as an opportunity to pursue pedagogical purposes and reduce the red tape of the PB. On the one hand, the PB was expected to foster a common language on, and understanding of, sustainability between the city council and citizens. On the other, this shift was expected to ensure a more straightforward analysis of citizen proposals and higher implementation rates. The streamlining of this process, therefore, was less a result of a shared understanding of its achievements, as-despite the step-by-step process towards urban sustainability theme via the Green Seal and the PB for schools- the announcement of the 2020 Green PB relied upon low evidence-based awareness of its contribution. These limits may have lowered the political ownership paired by an equally low rate of citizen participation in the first urban-sustainability-oriented PB in 2021. The systematisation of knowledge on the contribution of the PB to urban sustainability provided in this study, therefore, offers a review of the PB's achievements and contributes to our understanding and awareness of the reasons why, and the ways in which, such specific participatory arrangements can make a difference in citizen-centred sustainable policy-making. It thus translates the insights from Lisbon's case study into lessons for the improvement and advancement of $\mathrm{PB}$ as an additional mechanism that may respond to the global and local calls for change, and greater focus on sustainable urban futures.

\section{Conclusions}

Our study aimed to contribute to the participatory dimension of urban sustainability agendas through the specific lens of participatory budgets, by asking what are the lessons and potential contributions of the Lisbon PB experience towards urban sustainability, and analysing in detail Lisbon's developments in this field, keeping in mind the failed attempt to implement a Green PB in 2020, and the ongoing sustainability-oriented PB in 2021. Accordingly, this study presents and discusses the Lisbon PB experience and its achievements with a focus on the "environment, green structure and energy" thematic area, with the aim to understand its achievements and substantiate the potential to advance the city's urban sustainability agenda.

Our analysis reveals three interconnected findings. First, the Lisbon PB demonstrated considerable achievements in the "environment, green structure and energy" thematic area, corroborating the idea that citizens are indeed interested in promoting urban sustainability. Proposals and projects cover a wide range of topics, some of them showing the potential to 
go beyond an engineering-based vision of green spaces and infrastructure, as well as one less aligned with international agendas of climate change and biodiversity loss. Second, the achievements heavily depended on public action by the city council in deciding to invest in specific policies, with reverberations over the types of citizen demands to the PB. Finally, the shift towards a thematic PB in 2020 was not driven by social and political awareness of the PB achievements in terms of urban sustainability, but rather by the pursuit of pedagogical and instrumental (efficiency-led) purposes. The implementation of the 2021 sustainability-oriented $\mathrm{PB}$, however, widens its scope and is likely to hold a potential that may be further analysed in the future. We recommend that this kind of data collection and analysis should be systematically carried out and disseminated within city council departments, promoting much needed internal awareness of PBs' potential as drivers of urban sustainability. We also identify further research needs into the sustainability potential of green PBs.

At the time of this study, the $2021 \mathrm{~PB}$ edition is in progress and it is impossible to retrieve significant up-to-date insights from its outcomes that ought to be addressed in future research. However, we may interpret the low participation rate in the $2021 \mathrm{~PB}$ as the need to accommodate society to the idea that now the PB only funds citizen proposals in the field of urban sustainability. It might also relate to the reduced capacity of the city council to capitalise knowledge from past editions and raise awareness about the opportunity to reorientate the PB towards urban sustainability. Last, these data may also mean that the public attitude, interest, and trust towards the PB as a policy mechanism per se is declining. Likewise, we acknowledge three main limitations in our study that can hopefully inspire the scholarly debate. Firstly, the focus on one city (albeit a leader in this field) is inevitably limited, and international comparative analyses on the contribution of the PB in this field will enhance our understanding of the potential of citizen participation to advance urban sustainability. Secondly, the focus on the Lisbon PB thematic area "environment, green structure and energy" may have sidelined insights from other thematic areas, which could contribute to other aspects of urban sustainability, thus, future research should take into consideration citizen proposals and projects funded in all PB thematic areas for a more comprehensive picture of its achievements. Thirdly, an in-depth investigation into citizens' views of urban sustainability would make an important addition to this initial overview of Lisbon's experience.

Despite the limitations inherent to our exploratory study, our findings offer useful insights into the potential of participatory budgets in contributing towards more sustainable cities. As we enter the third decade of the 21st century, the pressure and hopes around the role of cities to fight climate change and contribute to reduce biodiversity loss is growing. Agendas, including those based on nature-based solutions, are building momentum and expectations. We believe that a better understanding of the PB potential can make an important contribution towards more sustainable futures, promoting greater awareness and commitment of both citizens and local governments.

Author Contributions: Conceptualization, R.F., J.V., and O.B.; methodology, R.F.; validation, R.F., J.V. and O.B.; formal analysis, R.F.; investigation, R.F., J.V., and O.B.; resources, R.F.; data curation, R.F.; writing-original draft preparation, R.F., J.V., and O.B.; writing-review and editing, R.F., J.V., and O.B.; visualization, R.F.; supervision, R.F.; project administration, R.F.; funding acquisition, R.F. and O.B. All authors have read and agreed to the published version of the manuscript.

Funding: This research was funded by Fundação para a Ciência e Tecnologia, grant number SFRH/BPD/109406/2015, and by CONEXUS, European Union Horizon 2020 Grant Agreement 867564.

Institutional Review Board Statement: Not applicable.

Informed Consent Statement: Not applicable.

Data Availability Statement: Data analysed in this article with reference to the Lisbon Participatory Budget can be found at: https:/ / op.lisboaparticipa.pt/, accessed on the 12 June 2021.

Conflicts of Interest: The authors declare no conflict of interest. 


\section{Appendix A}

Table A1. Citizen proposals, votes, winning projects, and public funding in the Lisbon PB.

\begin{tabular}{|c|c|c|c|c|c|c|c|c|c|c|c|c|}
\hline PB Editions & $\begin{array}{l}\text { Total of Citizen } \\
\text { Proposals (No.) }\end{array}$ & $\begin{array}{l}\text { Citizen Proposals } \\
\text { in the Thematic } \\
\text { Area (No.) }\end{array}$ & $\%$ & $\begin{array}{c}\text { Total of } \\
\text { Votes (No.) }\end{array}$ & $\begin{array}{l}\text { Votes in the Thematic } \\
\text { Area (No.) }\end{array}$ & $\%$ & $\begin{array}{l}\text { Total of Winning } \\
\text { Projects (No.) }\end{array}$ & $\begin{array}{l}\text { Winning Projects } \\
\text { in the Thematic } \\
\text { Area (No.) }\end{array}$ & $\%$ & $\begin{array}{c}\text { Total of } \\
\text { Public } \\
\text { Funding (€) }\end{array}$ & $\begin{array}{l}\text { Public Funding in } \\
\text { the Thematic Area } \\
\text { (€) }\end{array}$ & $\%$ \\
\hline 2008 & 89 & 62 & $70 \%$ & 1101 & 572 & $52 \%$ & 5 & 4 & $80 \%$ & $5,130,176$ & $4,550,000$ & $89 \%$ \\
\hline 2009 & 200 & 98 & $49 \%$ & 4719 & 1148 & $24 \%$ & 12 & 4 & $33 \%$ & $4,817,492$ & $1,825,000$ & $38 \%$ \\
\hline 2010 & 291 & 112 & $38 \%$ & 11,570 & 1722 & $15 \%$ & 7 & 3 & $42 \%$ & $4,500,000$ & $2,250,000$ & $50 \%$ \\
\hline 2011 & 228 & 86 & $38 \%$ & 17,887 & 4265 & $24 \%$ & 5 & 3 & $60 \%$ & $4,600,000$ & $2,600,000$ & $56 \%$ \\
\hline 2012 & 231 & 83 & $36 \%$ & 29,911 & 620 & $2 \%$ & 15 & 1 & $7 \%$ & $2,375,000$ & 100,000 & $4 \%$ \\
\hline 2013 & 208 & 85 & $41 \%$ & 35,922 & 11,788 & $33 \%$ & 16 & 5 & $31 \%$ & $2,475,000$ & 940,000 & $38 \%$ \\
\hline 2014 & 211 & 92 & $44 \%$ & 36,032 & $\begin{array}{l}71,100 \\
7386\end{array}$ & $20 \%$ & 13 & 3 & $23 \%$ & $2,428,000$ & $1,100,000$ & $45 \%$ \\
\hline 2015 & 189 & 75 & $40 \%$ & 42,130 & 5644 & $13 \%$ & 15 & 3 & $20 \%$ & $2,500,000$ & 800,000 & $32 \%$ \\
\hline 2016 & 182 & 38 & $21 \%$ & 51,591 & 11,595 & $22 \%$ & 17 & 7 & $41 \%$ & $2,480,000$ & $1,050,000$ & $42 \%$ \\
\hline 2017 & 128 & 28 & $22 \%$ & 37,673 & 5898 & $16 \%$ & 15 & 2 & $13 \%$ & $2,513,000$ & 300,000 & $12 \%$ \\
\hline 2018 & 122 & 26 & $21 \%$ & 34,672 & 4225 & & 19 & 3 & $16 \%$ & $2,505,000$ & 500,000 & $20 \%$ \\
\hline TOTAL & 2073 & 785 & $38 \%$ & & & $18 \%$ & 139 & 38 & $27 \%$ & $36,441,176$ & $16,015,000$ & $44 \%$ \\
\hline
\end{tabular}

\section{Appendix B}

Table A2. Proposals from the emerging topics in the thematic area "environment, green structure, and energy" of the Lisbon PB.

\begin{tabular}{|c|c|c|c|c|c|c|c|c|c|c|c|c|c|c|c|c|}
\hline \multirow[t]{2}{*}{ PB Editions } & \multicolumn{2}{|c|}{$\begin{array}{c}\text { Topic } 1 \\
\text { City/Neighbourhood }\end{array}$} & \multicolumn{2}{|c|}{$\begin{array}{c}\text { Topic } 2 \\
\text { Recovery }\end{array}$} & \multicolumn{2}{|c|}{$\begin{array}{c}\text { Topic } 3 \\
\text { Gardens }\end{array}$} & \multicolumn{2}{|c|}{$\begin{array}{c}\text { Topic } 4 \\
\text { Farming }\end{array}$} & \multicolumn{2}{|c|}{$\begin{array}{l}\text { Topic } 5 \\
\text { Mobility }\end{array}$} & \multicolumn{2}{|c|}{$\begin{array}{c}\text { Topic } 6 \\
\text { Animals }\end{array}$} & \multicolumn{2}{|c|}{$\begin{array}{l}\text { Topic } 7 \\
\text { Energy }\end{array}$} & \multicolumn{2}{|c|}{$\begin{array}{l}\text { Topic } 8 \\
\text { Pollution }\end{array}$} \\
\hline & No. & $\%$ & No. & $\%$ & No. & $\%$ & No. & $\%$ & No. & $\%$ & No. & $\%$ & No. & $\%$ & No. & $\%$ \\
\hline 2008 & 15 & $24 \%$ & 28 & $45 \%$ & 15 & $24 \%$ & 2 & $3 \%$ & 2 & $3 \%$ & 0 & $0 \%$ & 0 & $0 \%$ & 0 & $0 \%$ \\
\hline 2009 & 20 & $20 \%$ & 44 & $45 \%$ & 25 & $24 \%$ & 4 & $4 \%$ & 3 & $3 \%$ & 1 & $1 \%$ & 1 & $1 \%$ & 0 & $0 \%$ \\
\hline 2010 & 12 & $11 \%$ & 41 & $37 \%$ & 39 & $35 \%$ & 8 & $7 \%$ & 7 & $6 \%$ & 1 & $1 \%$ & 3 & $3 \%$ & 1 & $1 \%$ \\
\hline 2011 & 18 & $21 \%$ & 30 & $35 \%$ & 23 & $27 \%$ & 5 & $6 \%$ & 6 & $7 \%$ & 2 & $2 \%$ & 2 & $2 \%$ & 0 & $0 \%$ \\
\hline 2012 & 19 & $23 \%$ & 22 & $26 \%$ & 27 & $32 \%$ & 2 & $2 \%$ & 10 & $12 \%$ & 1 & $1 \%$ & 0 & $0 \%$ & 2 & $2 \%$ \\
\hline 2013 & 18 & $21 \%$ & 19 & $22 \%$ & 29 & $34 \%$ & 3 & $3 \%$ & 5 & $6 \%$ & 5 & $6 \%$ & 3 & $3 \%$ & 3 & $3 \%$ \\
\hline 2014 & 20 & $22 \%$ & 18 & $19 \%$ & 33 & $36 \%$ & 5 & $5 \%$ & 8 & $9 \%$ & 4 & $4 \%$ & 1 & $1 \%$ & 3 & $3 \%$ \\
\hline 2015 & 24 & $32 \%$ & 6 & $8 \%$ & 31 & $41 \%$ & 0 & $0 \%$ & 6 & $8 \%$ & 3 & $4 \%$ & 2 & $3 \%$ & 3 & $4 \%$ \\
\hline 2016 & 3 & $8 \%$ & 4 & $10 \%$ & 16 & $42 \%$ & 1 & $3 \%$ & 1 & $3 \%$ & 8 & $21 \%$ & 2 & $5 \%$ & 3 & $8 \%$ \\
\hline 2017 & 5 & $18 \%$ & 6 & $21 \%$ & 10 & $36 \%$ & 1 & $3 \%$ & 0 & $0 \%$ & 4 & $14 \%$ & 2 & $7 \%$ & 0 & $0 \%$ \\
\hline 2018 & 9 & $35 \%$ & 5 & $19 \%$ & 7 & $27 \%$ & 0 & $0 \%$ & 0 & $0 \%$ & 1 & $4 \%$ & 0 & $0 \%$ & 4 & $15 \%$ \\
\hline TOTAL & 163 & $21 \%$ & 223 & $28 \%$ & 255 & $32 \%$ & 31 & $4 \%$ & 48 & $6 \%$ & 30 & $4 \%$ & 16 & $2 \%$ & 19 & $2 \%$ \\
\hline
\end{tabular}

\section{References}

1. Pateman, C. Participation and Democratic Theory, 1st ed.; Cambridge University Press: Cambridge, UK, 1970.

2. Fung, A. Putting the Public Back into Governance: The Challenges of Citizen Participation and Its Future. Public Adm. Rev. 2015, 75, 513-522. [CrossRef]

3. Avritzer, L. New Public Spheres in Brazil: Local Democracy and Deliberative Politics. Int. J. Urban. Reg. Res. 2006, $30,623-637$. [CrossRef]

4. Baiocchi, G. Militants and Citizens: The Politics of Participatory Democracy in Porto Alegre; Stanford University Press: Stanford, CA, USA, 2005.

5. Dias, N.; Enríquez, S.; Júlio, S. The Participatory Budgeting World Atlas; Epopeia and Oficina: Faro, Portugal, 2019.

6. Falanga, R. Citizen Participation during the COVID-19 pandemic: Insights from Local Practices in European Cities. 2020. Available online: http:/ /library.fes.de/pdf-files/bueros/lissabon/17148.pdf (accessed on 30 December 2020).

7. Falanga, R.; Lüchmann, L. Participatory Budgets in Brazil and Portugal: Comparing Patterns of Dissemination. Policy Stud. 2020, 41, 603-622. [CrossRef]

8. Grimm, N.; Schindler, S. Nature of Cities and Nature in Cities: Prospects for Conservation and Design of Urban Nature in Human Habitat. In Rethinking Environmentalism: Linking Justice, Sustainability, and Diversity; Sharachchandra, L., Brondizio, E.S., Byrne, J., Mace, G.M., Martinez-Alier, J., Eds.; MIT Press: Cambridge, UK, 2018; pp. 99-125.

9. Simon, D.; Arano, A.; Cammisa, M.; Perry, B.; Pettersson, S.; Riise, J.; Valencia, S.; Oloko, M.; Sharma, T.; Vora, Y.; et al. Cities coping with COVID-19: Comparative perspectives. City 2021, 25, 1-42. [CrossRef]

10. Elmqvist, T.; Fragkias, M.; Goodness, J.; Güneralp, B.; Marcotullio, P.J.; McDonald, R.I.; Parnell, S.; Schewenius, M.; Sendstad, M.; Seto, K.C.; et al. Urbanization, Biodiversity and Ecosystem Services: Challenges and Opportunities; Springer: Berlin/Heidelberg, Germany, 2013.

11. Dorst, H.; van der Jagt, A.; Raven, R.; Runhaar, H. Urban Greening through Nature-Based Solutions-Key Characteristics of An Emerging Concept. Sustain. Cities Soc. 2019, 49, 101620. [CrossRef]

12. McCormick, K. Cities, Nature and Innovation: New Directions; Lund University: Lund, Sweden, 2020.

13. Brundtland Commission. Our Common Future. Report of the World Commission on Environment and Development; Oxford University Press: Oxford, UK, 1987. 
14. IPBES. Workshop Report on Biodiversity and Pandemics of the Intergovernmental Platform on Biodiversity and Ecosystem Services; IPBES: Bonn, Germany, 2020.

15. Rudd, A.; Simon, D.; Cardama, M.; Birch, E.L.; Revi, A. The UN, the Urban Sustainable Development Goal, and the New Urban Agenda. In Urban Planet: Knowledge towards Sustainable Cities; Griffith, C., Maddox, D., Simon, D., Watkins, M., Frantzeskaki, N., Romero-Lankao, P., Parnell, S., Elmqvist, T., McPhearson, T., Bai, X., Eds.; Cambridge University Press: Cambridge, UK, 2018; pp. 180-196.

16. Akande, A.; Cabral, P.; Gomes, P.; Casteleyn, S. The Lisbon Ranking for Smart Sustainable Cities in Europe. Sustain. Cities Soc. 2019, 44, 475-487. [CrossRef]

17. Bulkeley, H. Cities and Climate Change; Routledge: New York, NY, USA, 2013.

18. UNGA. Transforming Our World: The 2030 Agenda for Sustainable Development, UN General Assembly, Resolution Adopted by the General Assembly on 25 September 2015, Geneva; UN: Geneva, Switzerland, 2015.

19. UNCED. Agenda 21, United Nations Conference on Environment and Development, United Nations General Assembly. 1992. Available online: http:/ / www.unorg/esa/sustdev/agenda21texthtm13/12/02 (accessed on 23 March 2020).

20. UN. New Urban Agenda, Habitat III. 2017. Available online: https://unhabitat.org/sites/default/files/2019/05/nua-english.pdf (accessed on 15 July 2020).

21. Klopp, J.M.; Petretta, D.L. The Urban Sustainable Development Goal: Indicators, COMPLEXITY and the politics of Measuring Cities. Cities 2017, 63, 92-97. [CrossRef]

22. Rees, W.E. Is 'Sustainable City' An Oxymoron? Local Environ. 1997, 2, 303-310. [CrossRef]

23. Campbell, S. Green Cities, Growing Cities, Just Cities?: Urban Planning and the Contradictions of Sustainable Development. J. Am. Plan. Assoc. 1996, 62, 296-312. [CrossRef]

24. Connelly, S. Mapping Sustainable Development as A Contested Concept. Local Environ. 2007, 12, 259-278. [CrossRef]

25. Mitlin, D.; Satterthwaite, D. Sustainable Development and Cities. In Sustainability, the Environment and Urbanization; Pugh, C., Ed.; Earthscan, London and Sterling: London, UK, 1996.

26. Dempsey, N.; Brown, C.; Bramley, G. The Key to Sustainable Urban Development in UK Cities? The Influence of Density on Social Sustainability. Prog. Plan. 2012, 77, 89-141. [CrossRef]

27. McKenzie, S. Social Sustainability: Towards Some Definitions; Hawke Research Institute Working Paper Series, nr 27; University of South Australia: Adelaide, Australia, 2004.

28. Simon, D.; Palmer, H.; Rise, J. Comparative Urban Research from Theory to Practice: Co-Production for Sustainability; Policy Press: Bristol, UK, 2020.

29. Fokdal, J.; Bina, O.; Chiles, P.; Omajäe, L.; Paadam, K. Enabling the City: Inter- and Transdisciplinary Encounters; Routledge: New York, NY, USA, 2021.

30. Leipzig Charter. Leipzig Charter on Sustainable European Cities. 2007. Available online: https://english.leipzig.de/ construction-and-residence/urban-development/leipzig-2020-integrated-city-development-concept-seko/implementation/ leipzig-charter/ (accessed on 2 May 2007).

31. Kinzer, K. How Can We Help? An Exploration of the Public's Role in Overcoming Barriers to Urban Sustainability Plan Implementation. Sustain. Cities Soc. 2018, 39, 719-728. [CrossRef]

32. Trudeau, D. Integrating Social Equity in Sustainable Development Practice: Institutional Commitments and Patient Capital. Sustain. Cities Soc. 2018, 41, 601-610. [CrossRef]

33. Van der Steen, M.; Van Twist, M.; Chin-A-Fat, N.; Kwakkelstein, T. Pop-Up Public Value: Public Governance in the Context of Civic Self Organisation. 2013. Available online: http:/ / www.nsob.nl/wp-content/uploads/NSOB_Denktank_Pop-up-UK-DEFweb.pdf (accessed on 28 February 2020).

34. Van der Jagt, A.P.N.; Elands, B.H.M.; Ambrose-Oji, B.; Gerőházi, E.; Steen Møller, M.; Buizer, M. Participatory Governance of Urban Green Spaces: Trends and Practices in the EU. Nord. J. Archit. Res. 2016, 3, 11-40.

35. Lieberherr, E.; Odom Green, O. Green Infrastructure through Citizen Stormwater Management: Policy Instruments, Participation and Engagement. Sustainability 2018, 10, 2099. [CrossRef]

36. Mayer, A.L.; Shuster, W.D.; Beaulieu, J.J.; Hopton, M.E.; Rhea, L.K.; Roy, A.H.; Thurston, H.W. Building Green Infrastructure via Citizen Participation: A Six-Year Study in the Shepherd Creek (Ohio). Environ. Pract. 2012, 14, 57-67. [CrossRef]

37. Verheij, J.; Nunes, M. Justice and Power Relations in Urban Greening: Can Lisbon's Urban Greening Strategies Lead to More Environmental Justice? Local Environ. 2020, 26, 329-346. [CrossRef]

38. Wilker, J.; Rusche, K.; Rymsa-Fitschen, C. Improving Participation in Green Infrastructure Planning. Plan. Pract. Res. 2016, 31, 229-249. [CrossRef]

39. Hysing, E. Representative Democracy, Empowered Experts, and Citizen Participation: Visions of Green Governing. Environ. Polit. 2013, 22, 955-974. [CrossRef]

40. Portney, K.E.; Berry, J.M. Participation and the Pursuit of Sustainability in US Cities. Urban Aff. Rev. 2010, 46, 119-139. [CrossRef]

41. Polasky, S.; Caldarone, G.; Duarte, T.K.; Goldstein, J.; Hannahs, N.; Ricketts, T.; Tallis, H. Putting Ecosystem Service Models to Work: Conservation, Management, and Trade-offs. In Natural Capital: Theory and Practice of Mapping Ecosystem Services; Kareiva, P., Tallis, H., Ricketts, T.H., Daily, G.C., Polasky, S., Eds.; Oxford University Press: New York, NY, USA, 2011; pp. $249-263$.

42. Hayward, B.M. The Greening of Participatory Democracy: A Reconsideration of Theory. Environ. Polit. 1995, 4, 215-236. [CrossRef] 
43. Dryzek, J.S.; Pickering, J. Deliberation as A Catalyst for Reflexive Environmental Governance. Ecol. Econ. 2017, 131, 353-360. [CrossRef]

44. Dryzek, J.S. Rational Ecology: Environment and Political Economy; Basil Blackwell: Oxford, UK, 1987.

45. Stevenson, H.; Dryzek, J.S. The Discursive Democratisation of Global Climate Governance. Environ. Polit. 2012, $21,189-210$. [CrossRef]

46. Yearley, S. Green Ambivalence about Science: Legal-Rational Authority and the Scientific Legitimation of Social Movement. Br. J. Sociol. 1992, 43, 511-532. [CrossRef]

47. Paehlke, R. Democracy and Environmentalism: Opening A Door to the Administrative State. In Managing Leviathan. Environmental Politics and the Administrative State; Paehlke, R., Torgerson, D., Eds.; Broadview Press: Peterborough, ON, Canada, 2005; pp. 25-43.

48. Smith, G. Democratic Innovations. Designing Institutions for Citizen Participation; Cambridge University Press: Cambridge, UK, 2009.

49. Healey, P. Collaborative Planning: Shaping Places in Fragmented Societies; UBC Press: Newcastle, UK, 1997.

50. Sintomer, Y.; Herzberg, C.; Röcke, A.; Allegretti, G. Transnational Models of Citizen Participation: The Case of Participatory Budgeting. J. Public Delib. 2012, 8, 70-116. [CrossRef]

51. Cabannes, Y. Contributions of Participatory Budgeting to Climate Change Adaptation and Mitigation. Current Local Practices around the World E Lessons from the Field; IOPD: Barcelona, Spain, 2020.

52. Maksymiuk, G.; Kimic, K. 'Green Projects' in Participatory Budgets Inclusive Initiatives for Creating City's Top Quality Public Spaces. Warsaw Case Study. Warsaw University of Life Sciences-SGGW. 2016. Available online: https://core.ac.uk/download/ pdf/84251405.pdf (accessed on 30 March 2017).

53. Epting, S. Participatory Budgeting for Environmental Justice. Ethics Policy Environ. 2020, 23, 22-36. [CrossRef]

54. Balbona, D.L.; Bebega, S.G. Austerity and Welfare Reform in South-Western Europe: A Farewell to Corporatism in Italy, Spain and Portugal? Eur. J. Soc. Secur. 2015, 17, 271-291. [CrossRef]

55. Teles, F. Local Government and the Bailout: Reform Singularities in Portugal. Eur. Urban Reg. Stud. 2016, 23, 455-467. [CrossRef]

56. Allegretti, G.; Antunes, S. The Lisbon Participatory Budget: Results and Perspectives on An Experience in Slow but Continuous Transformation. Field Actions Sci. Rep. 2014, 11.

57. Buijs, A.E.; Elands, B.H.M.; Havik, G.; Ambrose-Oji, B.; Gerőházi, E.; Jagt van der, A.; Mattijssen, T.J.M.; Steen Møller, M.; Vierikko, K. Innovative Governance of Urban. Green Spaces: Learning from 18 Innovative Examples across Europe. Project ‘Green Surge' Research Report. 2016. Available online: https://research.wur.nl/en/publications/innovative-governance-of-urban-greenspaces-learning-from-18-inno (accessed on 31 January 2016).

58. EGC Evaluation Board. Expert Panel Technical Assessment Synopsis Report European Green Capital Award 2020. Available online: https:/ / ec.europa.eu/environment/europeangreencapital/press-communications/egca-publications/ (accessed on 27 January 2020).

59. Graça, M. Participação Pública: Mecanismos e Práticas No Contexto da Administração Pública e o Caso do Orçamento Participativo de Lisboa. Master's Thesis, ISCTE-Lisbon University Institute, Lisbon, Portugal, December 2018.

60. Gulsrud, N.M.; Ostoić, S.K.; Faehnle, M.; Maric, B.; Paloniemi, R.; Pearlmutter, D.; Simson, A.J. Challenges to Governing Urban Green Infrastructure in Europe-The Case of the European Green Capital Award. In The Urban Forest-Cultivating Green Infrastructure for People and the Environment; Pearlmutter, D., Calfapietra, C., O’Brien, L., Samson, R., Sanesi, G., Ostoic, S.K., del Amo, R.A., Eds.; Springer International Publishing: Berlin/Heidelberg, Germany, 2017.

61. Garcia-Lamarca, M.; Anguelovski, I.; Cole, H.; Connolly, J.T.; Arguelles, L.; Baro, F.; Loveless, S.; Pérez, C.; Shokry, G. Urban Green Boosterism and City Affordability: For Whom Is the 'Branded' Green City? Urban Stud. 2019, 58, 90-112. [CrossRef]

62. Sareen, S.; Grandin, J. European Green Capitals: Branding, Spatial Dislocation or Catalysts for Change? Geogr. Ann. Ser. B Hum. Geogr. 2019, 102, 101-117. [CrossRef] 